\title{
Introduction to Tractate Mo`ed Qatan
}

The Tractate also is known as Mašqin, from the first word of the first Mishnah, since the title "Mo`ed Qatan", minor holiday, is appropriate only for the first two Chapters. The topic is the rules for the intermediate days of Passover and Tabernacles which in the biblical text are designated as holidays of pilgrimage for which Temple ceremonies are specified in Lev., sacrifices in Num., and an obligation to celebrate the holidays in joy in Deut. The emphasis in the Tractate is on the interpretation of "celebrating the holiday in joy." The rabbinic rules are that agricultural and other gainful or professional work is permitted only if its omission would cause loss, except that day workers public works may be hired on holidays since this produces income to the poor and keeps costs down for the public. In addition, in order to force people to enter the holiday period well groomed, one forbids most grooming on the intermediate days. The exceptions are stated at the start of the third Chapter and since similar restrictions apply to mourners, the remainder of the Chapter is devoted to an exposition of burial and mourning rites. 